last month, "I view RANN and its predecessor (the programme was known last year as IRPOS) as a large experiment ... IRPOS has had no great successes of which it can boast-I hope the reason is only that it is young. Today, one cannot make any great claims that it has really solved a major problem which is pressing on our society."

Handler was also the only witness before the subcommittee to criticize the Administration's throttling of the NSF education programmes, particularly the fellowship and traineeship programmes. "I consider taking money from these two sets of programmes as a trend in the wrong direction. Both are on the road to extinction if this set of recommendations in this year's budget are indeed implemented, and I hope this would not be the case," Handler told the subcommittee. The form of the programmes was laid down two years ago by the National Science Board, of which Handler was then chairman. Evident from Handler's testimony, though not made explicit, was his disinclination to countenance the board's volte-face on this issue.

Of the four congressional committees that have to approve the NSF's budget (an authorization and appropriations committee in both House and Senate), the House Appropriations committee is the one that wields the greatest influence. Authorization committees are often regarded as special pleaders for the agencies with which they deal, and in the case of the National Science Foundation the House Appropriations committee has regularly slashed the annual budgets authorized by the Science, Research and Development subcommittee.

The usual sequence has been for the latter committee to authorize much more for the foundation than the President has requested in his budget and the Appropriations committee to appropriate much less. With new chairmen heading the relevant subcommittees, this year's scenario promises to be less dramatic. Davis's subcommittee apparently toyed with the idea of voting the foundation some $\$ 44$ million above the Administration request but decided this would be a face-losing gesture in view of the certain refusal of the appropriations committee to match such an increase.

The relevant subcommittee of the House Appropriations committee, the HUD-Space-Science subcommittee, has in Edward P. Boland a chairman who, if not yet a proved friend of science, is at least prepared to make amicable remarks about the foundation in public (see Nature, 230, 9; 1971). The indications are that Boland's subcommittee will vote the foundation much the same size of budget as the Administration is requesting.

\section{New Academy Members}

FIFTY new members were received into the bosom of the National Academy of Sciences at its annual meeting in Washington last week. In principle the members are elected on merit, subject to restrictions on the number of candidates from various disciplines. This year there was a quota of 18 for physical scientists, 18 for biological scientists and 10 for applied scientists (of both the physical and biological variety). The manner of appointment of the remaining 4 members is described in the accompanying article. The 50 new members are as follows:

Edward A. ADELBERG, microbiologist, Yale University ; Julius AXELROD, pharmacologist, National Institute of Mental Health; Lawrence BOGORAD, biologist, Harvard University; William F. BRACE, geologist, Massachusetts Institute of Technology ; Arthur M. BUECHE, General Electric Company; Allan M. CAMPBELL, biologist, Stanford University ; Marvin CHODOROW, electrical engineer, Stanford University; Arthur D. CODE, astronomer, University of Wisconsin ; Philip P. COHEN, physiologist, University of Wisconsin ; Mildred COHN, biophysicist, University of Pennsylvania.

George B. DANTZIG, operations research and computer science, Stanford University; Don U. DEERE, civil engineer, University of Illinois; Frank J. DIXON, pathologist, Scripps Clinic and Research Foundation; Kenneth $O$. EMERY, Woods Hole Oceanographic Institution; Josef FRIED, biochemist, University of Chicago; Alan GAREN, biophysicist, Yale University ; Riccardo GIACCONI, American Science and Engineering, Inc. ; Eleanor J. GIBSON, psychologist, Cornell University; Ward H. GOODENOÚGH, University of Pennsylvania; Luigi C. GORINI, bacteriologist, Harvard Medical School.

Harry B. GRAY, chemist, California Institute of Technology; Ernest M. GRUNWALD, chemist, Brandeis University; Arie J. HAAGEN-SMIT, chemist, California Institute of Technology; Norman HACKERMAN, Rice University; Vladimir HAENSEL, Universal Oil Products Company; David S. HEESCHEN, National Radio Astronomy Observatory; David H. HUBEL, physiologist, Harvard Medical School; William P. JENCKS, biochemist, Brandeis University ; Michael KASHA, chemist, Florida State University; Robert P. KRAFT, astronomer, University of California, Santa Cruz.

Hans W. LIEPMANN, aeronautical engineer, California Institute of Technology; Irving M. LONDON, physician, Albert Einstein College of Medicine ; Peter $\mathbf{R}$. MARLER, animal behaviour, Rockefeller University; Philip MORRISON, physicist, Massachusetts Institute of Technology; Jürgen $K$. MOSER, mathematician, New York University ; Earl L. MUETTERTIES, E. I. du Pont de Nemours \& Company ; Edward P. NEY, physicist, University of Minnesota ; William A. NIERENBERG, physicist, University of California, San Diego ; Irvine H. PAGE, Cleveland Clinic Foundation; William D. PHILLIPS, E. I. du Pont de Nemours \& Company.

Frederic M. RICHARDS, biophysicist, Yale University; Robert G. SACHS, physicist, Argonne National Laboratory; John R. SCHRIEFFER, physicist, University of Pennsylvania; Richard E. SCHULTES, botanist, Harvard University; Nevin S. SCRIMSHAW, nutritionist, Massachusetts Institute of Technology; Oliver SMITHIES, geneticist, University of Wisconsin; Hewson H. SWIFT, zoologist, University of Chicago ; John G. THOMPSON, mathematician, Cambridge University ; Sidney UDENFRIEND, molecular biologist, Roche Institute ; Gerald J. WASSERBURG, geophysicist, California Institute of Technology. In addition the posthumous election was announced of Otto Laporte, physicist at the University of Michigan at the time of his death.

The National Academy last week also elected the following 10 scientists as foreign associates:

Aage N. BOHR, physicist, Niels Bohr Institute, Denmark; Donald E. BROADBENT, psychologist, Cambridge, England ; Augusto GANSSER, geologist, Geologisches Institut, Switzerland; Dorothy C. HODGKIN, crystallographer, Oxford, England ; Aharon KATZIR-KATCHALSKY, chemist, Weizmann Institute of Science, Rehovot, Israel ; Vladimir I. KEILIS-BOROK, geologist, Academy of Sciences, USSR; Frantisek SORM, chemist, Czechoslovakia; Bengt STRÖMGREN, astronomer, University of Copenhagen, Denmark; Armen L. TAKHTADZHYAN, botanist, Komarov Botanical Institute, USSR ; Vincent $B$. WIGGLESWORTH, entomologist, Cambridge University, England.

The new elections bring the membership of the National Academy of Sciences up to 900 and the number of foreign associates up to 117 . Allen V. Astin, a former director of the National Bureau of Standards, was elected Home Secretary of the Academy, and the following 4 members were elected to the 12-man council that governs the academy and helps direct the National Research Council : Konrad E. Bloch of Harvard, Robert E. Marshak of the City College of New York, John R. Pierce of Bell Telephone Labs, and Harrison Shull of Indiana University. 